\title{
VARIASI KOMPOSISI BENTONIT PADA CETAKAN PASIR BLOK SILINDER MESIN PEMOTONG RUMPUT
}

\author{
Sofian Wijayanto ${ }^{1}$, Sunyoto ${ }^{2}$ \\ ${ }^{1,2}$ Pendidikan Teknik Mesin, Universitas Negeri Semarang \\ Email: sofianw117@gmail.com
}

\begin{abstract}
Purpose of this research is to find out how the influence of variation of bentonite composition on sand mold to casting defect, hardness and micro structure. Variations of bentonite composition used were 0\%, 8\% and $16 \%$. The data of the research were analyzed directly using graphs and micro photographs which were then drawn conclusions from the results of the study. Needle-hole defects are found in all variations of bentonite composition. The porosity defect was found only in the variation of $0 \%$ and $16 \%$ bentonit compositions. The highest hardness value was obtained from the $8 \%$ bentonite composition variation is $84.26 \mathrm{VHN}$ and the lowest hardness value was obtained from $0 \%$ VHN bentonit composition variation is $68.02 \mathrm{VHN}$. The best microstructure is indicated by the variation of $8 \%$ bentonite composition as evidenced by the formation of Al and Si elements that are evenly distributed and closer to the grain.
\end{abstract}

Keywords: bentonite composition, defect cast, hardness, microstructure

\begin{abstract}
ABSTRAK
Tujuan penelitian ini adalah untuk mengetahui bagaimana pengaruh variasi komposisi bentonit pada cetakan pasir terhadap cacat coran, kekerasan dan struktur mikro. Variasi komposisi bentonit yang digunakan adalah 0\%, 8\% dan 16\%. Data hasil penelitian dianalisis secara langsung menggunakan grafik dan foto mikro yang kemudian ditarik kesimpulan dari hasil penelitian tersebut. Cacat lubang jarum ditemukan di semua variasi komposisi bentonit. Sedangkan cacat porositas hanya ditemukan pada variasi komposisi bentonit $0 \%$ dan 16 . nilai kekerasan tertinggi diperoleh dari variasi komposisi bentonit $8 \%$ sebesar $84.26 \mathrm{VHN}$ dan nilai kekerasan terendah diperoleh dari variasi komposisi bentonit $0 \%$ sebesar 68.02 VHN. Struktur mikro terbaik ditunjukkan oleh variasi komposisi bentonit $8 \%$ dibuktikan dengan pembentukan unsur $\mathrm{Al}$ dan Si yang merata dan lebih merapat letak antar butirnya.
\end{abstract}

Kata kunci: komposisi bentonit, cacat coran, kekerasan, struktur mikro

\section{PENDAHULUAN}

Teknik pengecoran logam dituntut untuk dapat menghasilkan benda kerja yang bagus dan berkualitas dengan biaya yang rendah. sesuai dengan kebutuhan masyarakat. Pengecoran logam merupakan suatu proses manufaktur yang menggunakan logam cair dan cetakan untuk menghasilkan bentuk yang direncanakan. Coran dibuat dari logam yang dicairkan, dituang ke dalam cetakan, kemudian dibiarkan mendingin dan membeku (Surdia, 1976: 1). Cetakan yang digunakan diklasifikasikan menjadi dua kategori yaitu pengecoran dengan cetakan permanen dan pengecoran dengan cetakan sekali pakai.
Komposisi bentonit sebagai zat pengikat pada pasir cetak memiliki pengaruh terhadap daya ikat antara pasir, ikatan-ikatan pasir tersebut akan mempengaruhi berbagai sifat-sifat dari pasir cetak. Penambahan bentonit pada pasir cetak akan menguatkan ikatan cetakan tersebut, sehingga meningkatkan kekuatan tekan pasir, namun akan disertai juga dengan penurunan permeabilitas cetakan. Sebaliknya, penambahan bentonit yang kurang dari kadarnya, tidak akan memberikan kekuatan ikatan yang baik dalam pasir cetak tersebut (Budiyono, 2014: 2).

Blok silinder mesin pemotong rumput merupakan salah satu dari komponen otomotif yang dibuat menggunakan proses pengecoran 
berbahan aluminium. Disadari bahwa komponen otomotif yang dibuat menggunakan proses pengecoran harus memiliki standar mekanis tertentu, maka komponen tersebut harus memiliki jaminan akan kerusakan atau kegagalan akibat perpatahan dan jaminan aman dalam penggunaannya baik dalam jangka waktu singkat maupun jangka waktu panjang. Sehingga karakteristik sifat mekanis dan sifat fisis dari proses pengecoran logam sangat penting diketahui untuk peningkatan kualitas dan keamanan komponen otomotif yang digunakan. Selain itu diperlukan juga dinding liner silinder yang mempunyai nilai kekerasan yang tinggi dan nilai keausan yang rendah, agar tidak mudah terjadi kebocoran kompresi yang disebabkan oleh gesekan antara ring piston dan dinding liner silinder. (Diniardi, 2014: 1-2).

Tarkono (2013) melakukan penelitian dengan mencampurkan abu sekam dan bentonit. Dari penelitian tersebut disimpulkan bahwa sifat abu sekan dan bentonit yang diterapkan pada cetakan pasir, jumlah komposisinya mempengaruhi kekerasan hasil coran. Nilai kekerasan tertinggi dihasilkan pada komposisi bentonit $10 \%$ dan abu sekam $8 \%$ yang ditambahkan pada total komponen penyusun cetakan pasir. Nilai permeabilitas maksimum yang dicapai saat perbandingan abu sekam $8 \%$ dan bentonit $10 \%$ memberikan proses pendinginan yang lebih cepat sehingga berdampak pada peningkatan nilai kekerasan hasil coran aluminium AA 1100.

Tujuan dari penelitian ini adalah mengetahui bagaimana pengaruh variasi komposisi bentonit dalam cetakan pasir terhadap cacat coran, kekerasan dan struktur mkro. Variasi komposisi yang digunakan adalah $0 \%$, $8 \%$ dan $16 \%$.

\section{METODE}

Pada penelitian ini desain yang digunakan adalah desain penelitian eksperimen One Shot Case Study. Dalam penelitian ini, akan dilakukan perlakuan yang selanjutnya dilakukan observasi dengan pengujian cacat coran, kekerasan dan struktur mikro. Hasil akan dilakukan analisis deskriptif. Perlakuan yang akan dilakukan yaitu dengan memvariasikan komposisi bentonit pada cetakan pasir. Variasi komposisi bentonit yaitu $0 \%, 8 \%$ dan $16 \%$.

Tabel 1. Desain Penelitian

\begin{tabular}{ccc}
\hline $\begin{array}{c}\text { Komposisi } \\
\text { Dasar }\end{array}$ & Perlakuan & Hasil Penelitian \\
\hline \multirow{2}{*}{$\mathrm{X}$} & $\mathrm{X} 1$ & Y1 \\
& $\mathrm{X} 2$ & Y2 \\
& $\mathrm{X} 3$ & Y3 \\
\hline
\end{tabular}

Keterangan:

$\mathrm{X}=$ Pasir Cetak

$\mathrm{X} 1=$ Variasi Komposisi Bentonit 0\%

$\mathrm{X} 2=$ Variasi Komposisi Bentonit 8\%

$\mathrm{X} 3=$ Variasi Komposisi Bentonit 16\%

$\mathrm{Y} 1$ = Pengamatan Cacat Coran

Y2 $=$ Pengujian Nilai Kekerasan

Y3 = Pengamatan Struktur Mikro

\section{HASIL DAN PEMBAHASAN}

Berikut ini adalah hasil analisis cacat coran yang disajikan pada Gambar 1 sampai Gambar 6.

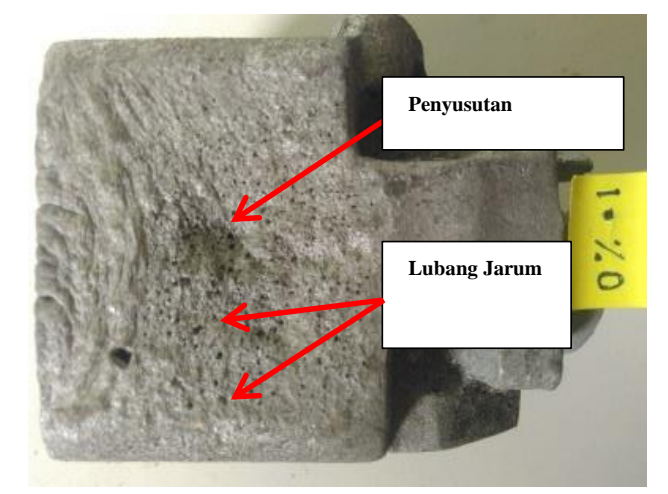

Gambar 1. Cacat coran bagian atas Bentonit 0\%

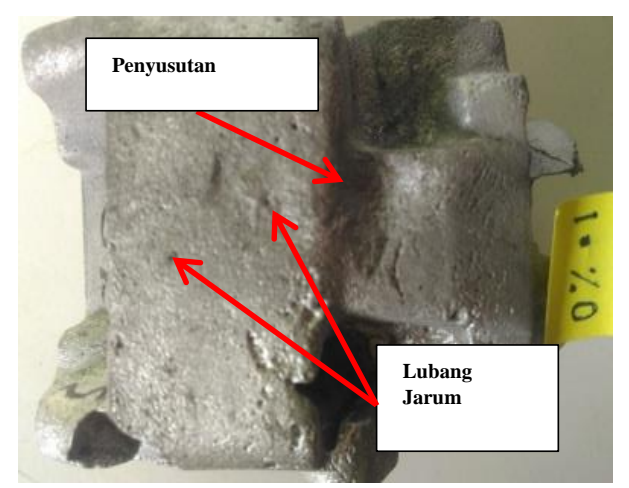

Gambar 2. Cacat coran bagian bawah Bentonit 0\% 
Spesimen dengan komposisi bentonit $0 \%$ bagian permukaan atas dan bawah terdapat banyak cacat lubang jarum dan terdapat cacat porositas

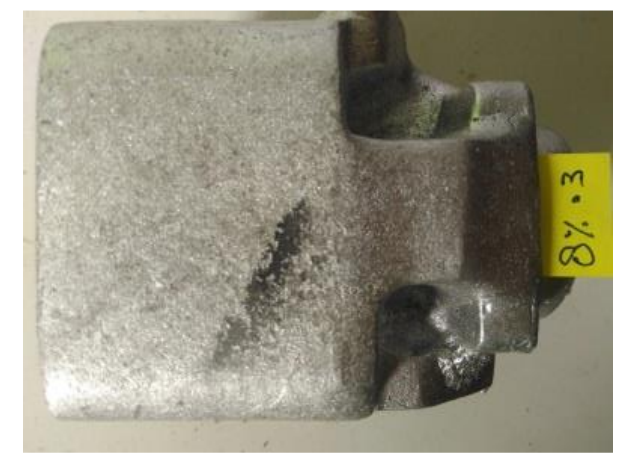

Gambar 3. Cacat coran bagian atas Bentonit $8 \%$

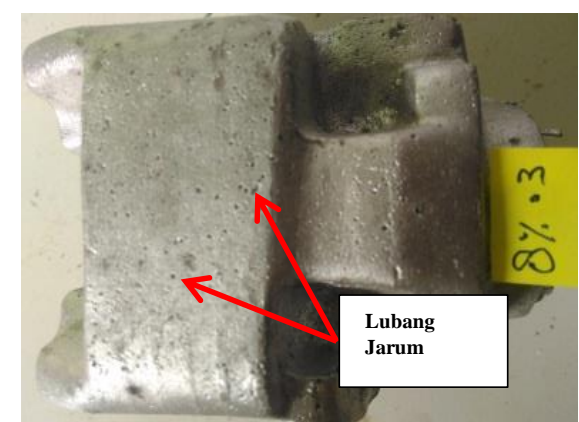

Gambar 4. Cacat coran bagian bawah Bentonit $8 \%$

Spesimen dengan komposisi bentonit $8 \%$ bagian permukaan atas tidak ditemukan cacat lubang jarum maupun cacat penyusutan. Bagian permukaan bawah ditemukan cacat lubang jarum yang jumlahnya lebih sedikit dibandingkan dengan variasi komposisi bentonit $0 \%$.

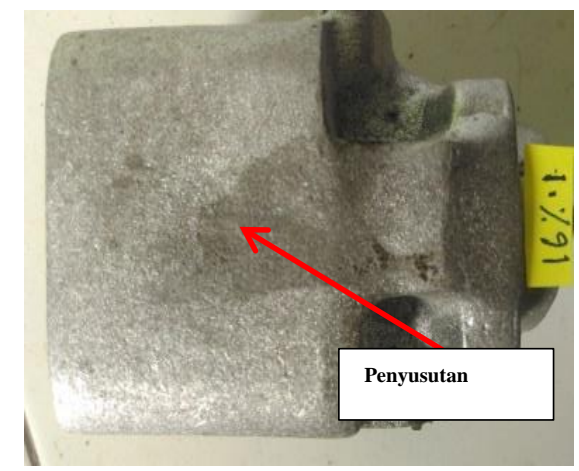

Gambar 5. Cacat coran bagian atas Bentonit 16\%

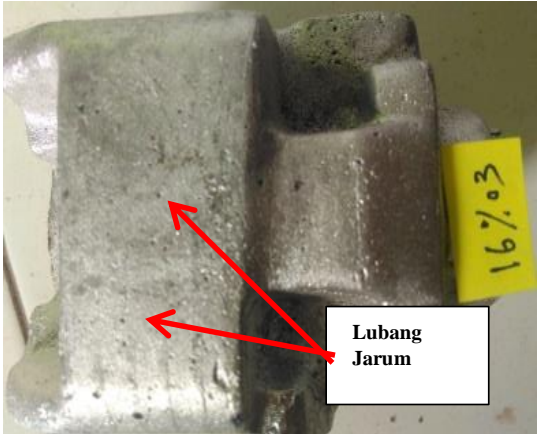

Gambar 6. Cacat coran bagian bawah Bentonit $16 \%$

Spesimen dengan komposisi bentonit $16 \%$ bagian permukaan atas ditemukan cacat penyusutan. Bagian permukaan bawah ditemukan cacat lubang jarum yang jumlahnya lebih sedikit dibandingkan spesimen variasi komposisi $0 \%$ dan lebih banyak dibandingkan variasi komposisi bentonit $8 \%$

Hasil Uji Kekerasan. Kekerasan merupakan ukuran ketahanan material terhadap deformasi plastis terlokalisasi (missal: “indentasi kecil” atau gores) (Sofyan, 2011: 34). Tujuan dilakukan uji kekerasan adalah untuk mengetahui tingkat kekerasan dari material tersebut. Pengujian kekerasan pada penelitian ini dilakukan dengan menggunakan alat uji kekerasan mikro vickers dengan pembebanan 100 gf selama 10 s. penekanan dilakukan sebanyak 4 titik pada setiap spesimen, dimana 2 titik penekanan pada bagian permukaan luar dan 2 titik pada permukaan dalam.

Tabel 2. Hasil Uji Kekerasan Vickers

\begin{tabular}{|c|c|c|c|c|c|c|}
\hline \multirow{3}{*}{ Var. } & \multirow{3}{*}{$\begin{array}{l}\text { Spes } \\
\text { imen }\end{array}$} & \multicolumn{4}{|c|}{ Nilai Kekerasan Vickers } & \multirow{3}{*}{ Mean } \\
\hline & & \multicolumn{2}{|c|}{$\begin{array}{c}\text { Permukaan } \\
\text { Luar }\end{array}$} & \multicolumn{2}{|c|}{$\begin{array}{c}\text { Permukaan } \\
\text { Dalam }\end{array}$} & \\
\hline & & 1 & 2 & 1 & 2 & \\
\hline \multirow{4}{*}{$0 \%$} & 1 & 59.20 & 68.20 & 52.40 & 67.70 & 61.88 \\
\hline & 2 & 73.80 & 88.80 & 67.90 & 65.30 & 73.95 \\
\hline & 3 & 86.50 & 85.80 & 78.90 & 75.90 & 81.78 \\
\hline & Mean & \multicolumn{2}{|c|}{77.05} & \multicolumn{2}{|c|}{68.02} & 72.53 \\
\hline \multirow{4}{*}{$8 \%$} & 1 & 88.60 & 80.90 & 90.10 & 78.10 & 84.43 \\
\hline & 2 & 80.60 & 76.80 & 107.00 & 109.20 & 93.40 \\
\hline & 3 & 75.50 & 75.90 & 76.50 & 71.90 & 74.95 \\
\hline & Mean & \multicolumn{2}{|c|}{79.72} & \multicolumn{2}{|c|}{88.80} & 84.26 \\
\hline
\end{tabular}




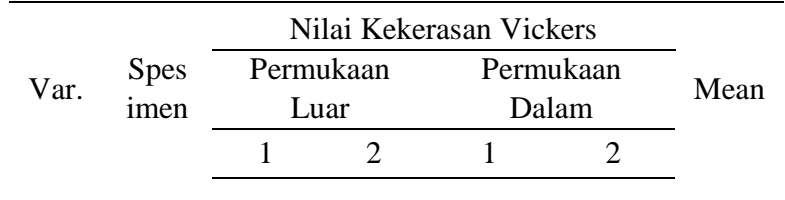

\begin{tabular}{|c|c|c|c|c|c|c|}
\hline \multirow{4}{*}{$16 \%$} & 1 & 73.9 & 74.4 & 94.1 & 69.7 & 78.03 \\
\hline & 2 & 80.5 & 89.6 & 83 & 66.1 & 79.80 \\
\hline & 3 & 74 & 85.7 & 67.7 & 79.3 & 76.68 \\
\hline & Mean & \multicolumn{2}{|c|}{79.68} & \multicolumn{2}{|c|}{76.65} & 78.17 \\
\hline
\end{tabular}

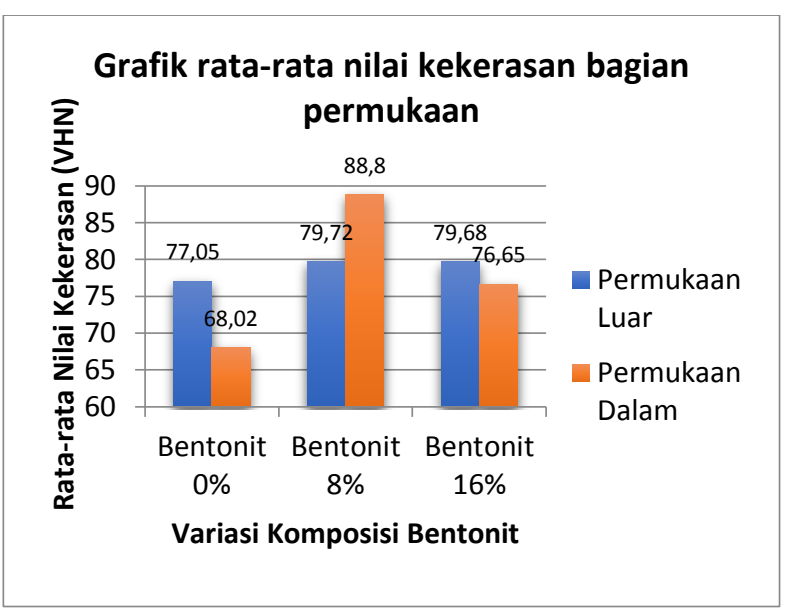

Gambar 7. Grafik Rata-rata Kekerasan Bagian Permukaan

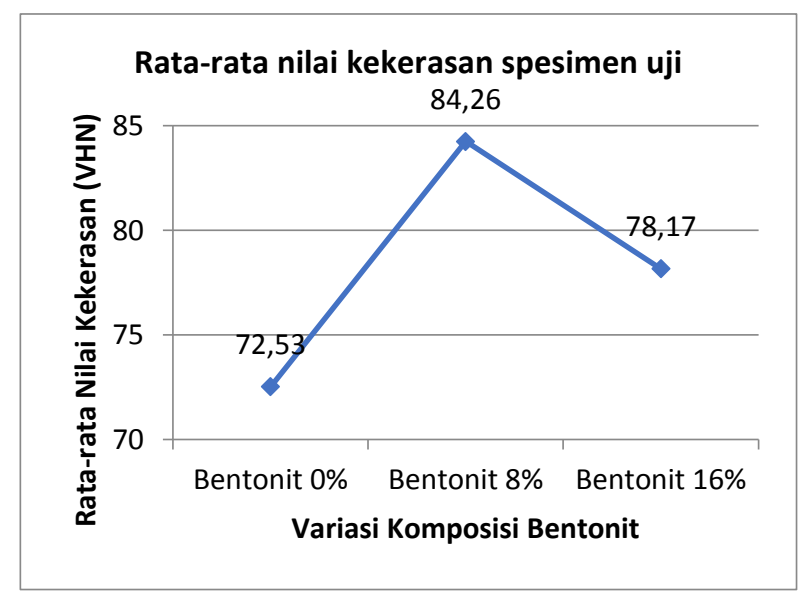

Gambar 8. Grafik Rata-rata Nilai Kekerasan Spesimen Uji

Hasil Struktur Mikro. Analisis struktur mikro terdiri dari 4 langkah utama yaitu sampling, preparasi sampel, pengambilan gambar, dan perhitungan ukuran porositas/butir.
Pengambilan gambar dilakukan dengan kamera menggunakan film atau digital (Ngatijo, 2009: 285).

Menurut Geger Kokok dalam Sinung Khoirrudin, dkk (2014: 5), struktur mikro yang terjadi pada aluminium coran, ditentukan oleh temperatur pemanasan saat pengecoran, laju pendinginan setelah pengecoran, laju pembekuan, komposisi kimia, logam induk, logam pengisi, dan perlakuan yang diterapkan pada aluminium tersebut.

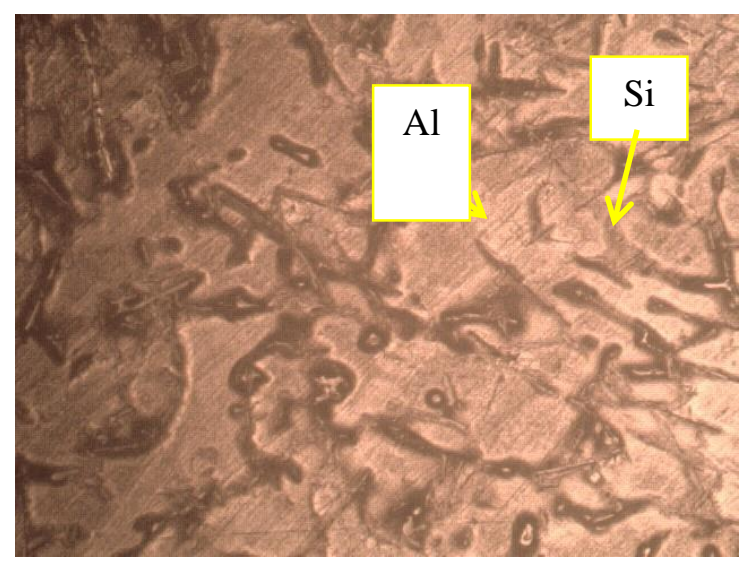

Gambar 9. Foto mikro komposisi bentonit $0 \%$

Gambar 9 menunjukkan bahwa foto struktur mikro variasi komposisi bentonit $0 \%$ dapat dideskripsikan pembentukan Si terhadap Al memiliki susunan yang lebih renggang dan $\mathrm{Si}$ memiliki ukuran yang besar dan panjang

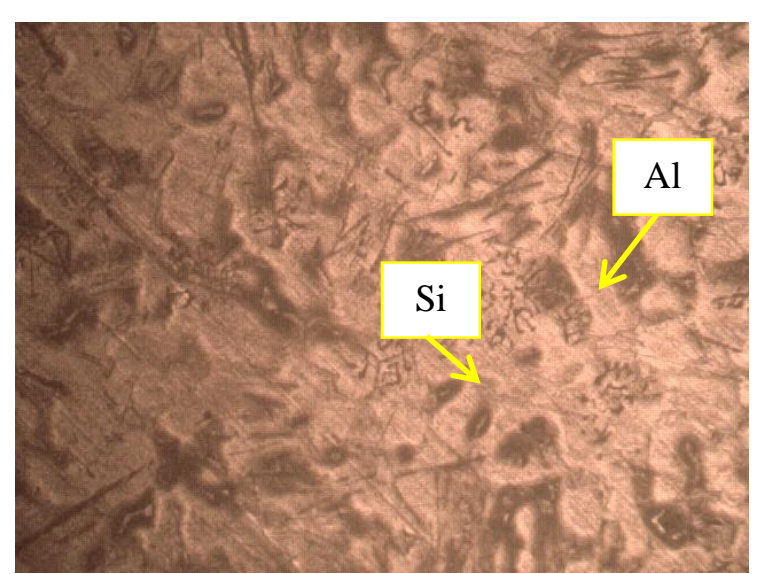

Gambar 10. Foto mikro komposisi bentonit 8\% 
Susunan Al-Si yang terbentuk pada variasi komposisi bentonit 8\% (gambar 10) menunjukkan pembentukan Si terhadap Al tidak merata dan mengelompok serta memiliki ukuran Si yang kecil dan susunannya rapat.

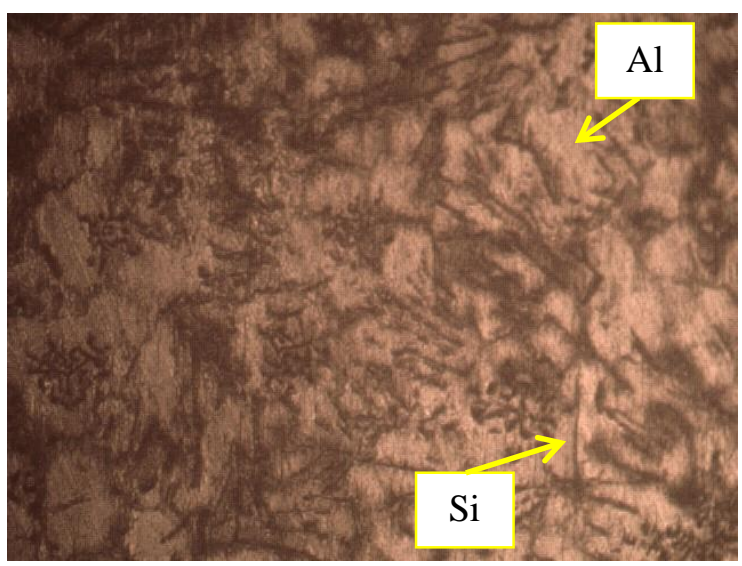

Gambar 11. Foto mikro komposisi bentonit $16 \%$

Foto mikro yang terbentuk pada variasi komposisi bentonit $16 \%$ (gambar 11) menunjukkan pembentukan $\mathrm{Si}$ terhadap $\mathrm{Al}$ memiliki susunan yang rapat dan $\mathrm{Si}$ memiliki ukuran yang panjang.

Cacat Coran. Berdasarkan hasil visual inspection yang dilakukan pada hasil coran blok silinder mesin pemotong rumput dengan menggunakan 3 variasi cetakan yang berbeda yaitu dengan komposisi bentonit $0 \%, 8 \%$ dan $16 \%$ dihasilkan cacat coran yang berbeda. Pengamatan dilakukan setelah proses pembongkaran benda dari cetakan untuk mengamati cacat lubang jarum dan cacat penyusutan yang terjadi pada benda.

Spesimen dengan komposisi bentonit $0 \%$. Berdasarkan inspeksi yang dilakukan pada benda hasil coran menggunakan cetakan pasir dengan komposisi bentonit $0 \%$ ditemukan cacat penyusutan dan cacat lubang jarum. Terdapat cacat penyusutan permukaan yang terlihat sangat jelas pada bagian atas spesimen seperti yang ditunjukkan gambar 1. Hal tersebut dapat terjadi karena permeabilitas pasir cetak yang kurang baik dan kurangnya saluran keluar pada cetakan yang mengakibatkan pasir cetak tidak dapat mengalirkan gas yang timbul saat proses penuangan logam ke dalam cetakan sehingga udara terperangkap di dalam cetakan. Terdapat cacat lubang jarum pada bagian atas spesimen, hal tersebut dapat terjadi karena terlalu banyak gas yang ditimbulkan dari cetakan pasir. Cacat lubang jarum juga ditemukan pada bagian bawah spesimen seperti pada gambar 2 namun jumlahnya lebih sedikit dibandingkan pada permukaan atas spesimen.

Spesimen dengan komposisi bentonit $8 \%$. Berdasarkan hasil inspeksi yang dilakukan pada benda hasil coran menggunakan cetakan pasir dengan komposisi bentonit $8 \%$ hanya ditemukan cacat lubang jarum yang jumlahnya lebih sedikit dibandingkan dengan variasi komposisi bentonit $0 \%$. Cacat lubang jarum yang ditemukan pada bagian bawah permukaan disebabkan oleh kurangnya saluaran keluar pada cetakan sehingga masih ada udara yang terperangkap di dalam cetakan. Tidak ditemukan cacat penyusutan pada variasi komposisi bentonit $8 \%$.

Spesimen dengan komposisi bentonit $8 \%$. Berdasarkan hasil inspeksi yang dilakukan pada benda hasil coran menggunakan cetakan pasir dengan komposisi bentonit $16 \%$ pada ditemukan cacat penyusutan dan cacat lubang jarum. Cacat penyusutan hanya ditemukan pada bagian permukaan atas yang ukurannya lebih kecil dibandingan dengan variasi komposisi bentonit $0 \%$. Cacat lubang jarum masih ditemukan pada variasi ini baik dibagian atas maupun bawah spesimen yang jumlahnya lebih banyak dari variasi komposisi bentonit $8 \%$ dan lebih sedikit dari variasi komposisi bentonit $0 \%$.

Uji Kekerasan. Tabel 2 menunjukkan bahwa nilai kekerasan pada cetakan pasir cengan variasi komposisi bentonit $0 \%, 8 \%$ dan $16 \%$ yang dominan lebih tinggi adalah variasi komposisi bentonit $8 \%$. Hal tersebut menunjukkan bahwa proses pencetakan logam aluminium menggunkan cetakan pasir dengan variasi komposisi bentonit mengakibatkan terjadinya perubahan ukuran butir dan struktur pada 
cetakan sehingga menghasilkan sifat permeabilitas pasir yang berbeda.

Nilai kekerasan spesimen dengan variasi komposisi bentonit 0\%. Berdasarkan tabel dapat diketahui rata-rata nilai kekerasan pada bagian permukaan luar sebesar 77.05 VHN lebih besar dibandingkan dengan permukaan bagian dalam yang memiliki nilai kekerasan rata-rata sebesar 68.02 VHN. sedangkan nilai rata-rata keseluruhan yang didapat dari uji kekerasan spesimen dengan variasi komposisi bentonit $0 \%$ adalah 72.53 VHN.

Nilai kekerasan spesimen dengan variasi komposisi bentonit $8 \%$. Berdasarkan tabel dapat diketahui rata-rata nilai kekerasan pada bagian permukaan luar sebesar 79.72 VHN lebih kecil dibandingkan dengan permukaan bagian dalam yang memiliki nilai kekerasan rata-rata sebesar 88.80 VHN. sedangkan nilai rata-rata keseluruhan yang didapat dari uji kekerasan spesimen dengan variasi komposisi bentonit $8 \%$ adalah 84.26 VHN, nilai tersebut lebih tinggi dibandingkan dengan variasi komposisi bentonit $0 \%$, hal tersebut berkaitan dengan semakin cepatnya laju pembekuan yang dipengaruhi nilai permeabilitas pasir.

Nilai kekerasan spesimen dengan variasi komposisi bentonit $16 \%$. Berdasarkan tabel dapat diketahui rata-rata nilai kekerasan pada bagian permukaan luar sebesar 79.68 VHN lebih besar dibandingkan dengan permukaan bagian dalam yang memiliki nilai kekerasan rata-rata sebesar 76.65 VHN. sedangkan nilai rata-rata keseluruhan yang didapat dari uji kekerasan spesimen dengan variasi komposisi bentonit $0 \%$ adalah 78.17 VHN, nilai tersebut lebih tinggi dibandingkan dengan variasi komposisi bentonit $0 \%$ namun lebih rendah dibandingkan dengan variasi komposisi bentonit $8 \%$.

Berdasarkan uraian data diatas menunjukkan bahwa variasi komposisi bentonit pada pasir cetak mempengaruhi nilai kekerasan pada hasil coran. Sejalan dengan penelitian Alyani (2009) yang menyatakan bahwa komposisi bentonit mempengaruhi nilai kekerasan. Komposisi bentonit pada cetakan pasir mempengaruhi besar butir pasir sehingga berpengaruh terhadap permeabilitas pasir cetak tersebut. Semakin tingginya nilai permeabilitas sebuah cetakan pasir maka semakin meningkatkan kecepatan proses pendinginan logam panas yang terdapat dalam cetakan pasir.

Struktur Mikro. Berdasarkan foto mikro yang telah dilakukan menunjukkan bahwa foto struktur mikro variasi komposisi bentonit $0 \%$ (Gambar 9) dapat dideskripsikan bahwa pembentukan Si terhadap Al memiliki susunan yang lebih renggang dan $\mathrm{Si}$ memiliki ukuran yang besar dan panjang. Susunan Al-Si yang terbentuk pada variasi komposisi bentonit $8 \%$ (gambar 10) menunjukkan pembentukan $\mathrm{Si}$ terhadap Al tidak merata dan mengelompok serta memiliki ukuran $\mathrm{Si}$ yang kecil dan susunannya rapat. Foto mikro yang terbentuk pada variasi komposisi bentonit 16\% (gambar 11) menunjukkan pembentukan Si terhadap $\mathrm{Al}$ memiliki susunan yang rapat dan Si memiliki ukuran yang panjang.

Pembentukan struktur pada hasil coran ditentukan oleh laju pembekuan. Ketika coran mempunyai laju pembekuan yang lama, maka struktur Al dan Si akan renggang dan kasar. Apabila hasil coran memiliki laju pembekuan yang cepat, maka struktur $\mathrm{Al}$ dan $\mathrm{Si}$ yang terbentuk akan merapat dengan jarak antar partikelnya berdekatan dan cenderung lebih halus. Struktur yang paling baik adalah spesimen variasi komposisi bentonit $8 \%$, dimana butir $\mathrm{Si}$ terlihat rapat dan lebih halus.

Berdasarkan hasil penelitian dengan variasi komposisi bentonit dadapatkan hasil bahwa spesimen dengan variasi komposisi bentonit $8 \%$ memiliki hasil yang lebih baik. Variasi komposisi bentonit $8 \%$ memiliki sedikit cacat coran, hal tersebut terjadi karena komposisi bentonit $8 \%$ yang terkandung dalam cetakan pasir menyebabkan permeabilitas pasir menjadi lebih baik, sejalan dengan penelitian yang dilakukan oleh Tarkono (2013) yang menyatakan bahwa perbedaan nilai permeabilitas mempengaruhi kecepatan pendinginan logam dalam cetakan. 
permaebilitas yang baik dapat mengalirkan udara keluar lebih mudah sehingga tidak terperangkap didalam cetakan yang akan mengakibatkan cacat pada hasil coran. Selain cacat coran, komposisi bentonit $8 \%$ juga memberikan hasil yang lebih baik pada nilai kekerasan. Hal tersebut dapat terjadi karena nilai kekerasan dalam sebuah proses pengecoran logam dapat dipengaruhi oleh kecepatan proses pendinginan yang dipengaruhi oleh nilai permeabilitas cetakan tersebut, oleh karena itu semakin tingginya nilai permeabilitas sebuah cetakan pasir maka semakin meningkatkan kecepatan proses pendinginan logam panas yang terdapat dalam cetakan pasir.

Cetakan pasir dengan komposisi bentonit 8\% memberikan permeabilitas yang cocok untuk meningkatkan nilai kekerasan. seperti yang dijelaskan (Setiawan 1997) dalam Tarkono (2013) Bila kadar bentonit di dalam campuran pasir cetak dianggap rendah, menyebabkan kekuatan pasir cetak menurun. Hal ini disebabkan karena daya ikat antar butir pasir cetak rendah. Bila kadar bentonit tinggi menyebabkan kekuatan pasir cetak meningkat dan cetakan menjadi padat. Padatnya pasir cetak menyebabkan permeabilitas turun sehingga sulit dilalui udara. Hal tersebut yang terjadi pada spesimen dengan variasi komposisi bentonit $16 \%$, dimana diduga terlalu banyak kandungan bentonit dalam cetakan pasir yang menyebabkan permeabilitas turun sehingga sulit dilalui udara. Variasi komposisi bentonit $8 \%$ juga mempunyai hasil struktur mikro yang paling baik. Hal tersebut juga disebabkan laju pembekuan cairan logam yang paling cepat sehingga unsur $\mathrm{Si}$ terbentuk lebih halus dan merata.

\section{SIMPULAN}

Hasil sajian data dan pembahasan menunjukkan bahwa 1) Variasi komposisi bentonit pada cetakan pasir berpengaruh terhadap cacat coran yang terbentuk. Cacat lubang jarum ditemukan di semua variasi komposisi bentonit. Sedangkan cacat porositas hanya ditemukan pada variasi komposisi bentonit $0 \%$ dan $16 \%$, dan tidak ditemukan pada variasi komposisi bentonit $8 \%$, 2) Variasi komposisi bentonit pada cetakan pasir berpengaruh terhadap nilai kekerasan microvickers yang dihasilkan. Untuk mencapai nilai kekerasan tertinggi, komposisi bentonit dalam pasir cetak harus diperhintungkan, dalam penelitian ini nilai kekerasan tertinggi diperoleh dari variasi komposisi bentonit $8 \%$ sebesar 84.26 VHN. dan nilai kekerasan terendah diperoleh dari variasi komposisi bentonit $0 \%$ sebesar 68.02 VHN, dan 3) Variasi komposisi bentonit pada cetakan pasir berpengaruh terhadap struktur mikro yang terbentuk. Berdasarkan hasil pengujian struktur mikro penyebaran distribusi partikel menunjukkan hasil yang berbeda. Struktur terbaik ditunjukkan oleh variasi komposisi bentonit $8 \%$ dibuktikan dengan pembentukan unsur $\mathrm{Al}$ dan $\mathrm{Si}$ yang merata dan lebih merapat letak antar butirnya.

\section{DAFTAR RUJUKAN}

Alyani, Z., Amin, M., Faizul, C.P., Ichwan, M. and Nasution, P.M., 2009. Properties of Zinc alloy cast product with different composition of Silica Sand and Bentonite in Green Sand Mould.

Budiyono, S., 2014. Perbandingan kualitas hasil pengecoran pasir cetak basah dengan campuran bentonit $3 \%$ dan $5 \%$ pada besi cor kelabu. Jurnal Nosel, 2(3).

Diniardi, E., Ramadhan, A.I., Kirono, S. and Julianto, A., 2014. Analisa Kekerasan dan Laju Keausan Blok Silinder Mesin Sepeda Motor Berbahan Paduan Al-si. Prosiding Semnastek,1(1).

Khoirrudin, S., 2014. Pengaruh Variasi Jumlah Saluran Masuk Terhadap Struktur Mikro, Kekerasan, dan Ketangguhan Pengecoran Pulley Paduan Aluminium Al-Si Menggunakan Cetakan Pasir. Jurnal Nosel, 3(1).

Ngatijo., S. Pribadi. dan A. Sartono. 2009. Analisis Struktur-Mikro Pelet Uranium Oksida Sinter. Hasil Penelitian EBN ISSN 0854-5561: 285-291 
Tarkono. and Sewandono, D., 2013. Pengaruh Variasi Abu Sekam Dan Bentonit Pada Cetakan Pasir Terhadap Kekerasan Dan Struktur Mikro 2) 1) Hasil Coran Alumunium Aa 1100. Jurnal Ilmiah Teknik Mesin, 1(3).
Sofyan, B.T. 2010. Pengantar Material Teknik. Jakarta: Salemba Teknika.

Surdia, T. dan Kenji C. 1976. Teknik Pengecoran Logam. Cetakan Kedua. Jakarta: PT. Pradnya Paramita 